found themselves among people with an ancient civilization, particularly among those with some literate tradition, as for example in Central Asia, Persia, the Ottoman Empire, China, and Japan, they discovered that local acceptance could be gained through use of local language.

Il'minskii, therefore, can be better understood when seen in the wider context of nineteenth-century mission activities. In this context, his language policy is not unique or original but has antecedents in the work of Western missionaries in areas contiguous to the tsarist empire.

EDEN NaBY

East Asian Research Institute, Harvard University

\title{
To THE EDITOR:
}

The interesting article by Russell Zguta, "The Ordeal by Water (Swimming of Witches) in the East Slavic World" (Slavic Review, June 1977), prompts a brief comment. In a lengthy footnote (p. 222) the author states that in Russia, in contrast to Western Europe, men were the victims of witchhunts as often as women. As evidence, court records are cited showing that in the seventeenth century there were more men than women tried for witchcraft. The difference between Russian and Western attitudes is attributed to a Western scholastic tradition which held that "as members of the 'weaker sex,' [women] were far more susceptible to Satan's wiles." In medieval Russia, the author argues, "no such distinction between the sexes existed, except in cases of drought and famine."

The contrast is arresting, but the implication that Russian women were relatively better off in this connection (with respect to either Russian men or Western women) appears questionable. In fact, the documentary testimony is open to quite another interpretation: namely, that women had less opportunity than did men for legal defense against a charge of witchery. According to the Entsiklopedicheskii slovar' article, "Zhenshchina," medieval specialists have estimated that for every male accused of witchcraft there were ten thousand women accused. The judicial records complement the author's own evidence on the ordeal by water to suggest in fact that Russian women were not treated more leniently than men, but on the contrary were subject to more summary forms of "justice."

There appears to be a stronger parallel here than a contrast to Western experience. And perhaps the parallel can be explained by the presence of a Russian strain of that same "scholastic tradition" found in the West. In some quarters at least, a distinction relating to witchcraft did indeed exist between the sexes. The Russian Primary Chronicle (p. 153 of the Cross translation cited by the author) counseled and cautioned Russians most explicitly on this point: "Particularly through the agency of woman are infernal enchantments brought to pass, for in the beginning the devil deceived woman, and she in turn deceived man."

Dorothy AtKinson

Stanford University

\section{TO THE EDITOR:}

Will you kindly allow me a few paragraphs concerning Professor Winters's review of my latest book, The Masaryks (Slavic Review, June 1977, pp. 337-38)?

I should say straightaway that I wrote The Masaryks as an intermediate book: intermediate between years of research and writing on subjects closely connected with the lives of the Masaryks on the one hand and, on the other, a full-length, detailed 